\title{
Placenta-Derived Decidua Stromal Cells for Hemorrhagic Cystitis after Stem Cell Transplantation
}

\author{
Wictor Aronsson-Kurttila ${ }^{a}$ Arjang Baygan ${ }^{a}$ Gianluca Moretti ${ }^{\mathrm{a}}$ \\ Mats Remberger $^{b}$ Bita Khoein ${ }^{a}$ Guido Moll ${ }^{a, c, d}$ Behnam Sadeghi ${ }^{a}$ \\ Olle Ringdén ${ }^{\text {a }}$
}

${ }^{a}$ Division of Translational Cell Therapy Research (TCR), Department of Laboratory Medicine, Karolinska Institutet, and ${ }^{b}$ Center for Allogeneic Stem Cell Transplantation, Karolinska University Hospital Huddinge, Stockholm, Sweden; ${ }^{c}$ Charité - Universitätsmedizin and d Berlin-Brandenburg Center and School for Regenerative Therapies (BCRT/BSRT), Berlin, Germany

\section{Keywords}

Allogeneic stem cell transplantation · Hemorrhagic cystitis · Mesenchymal stromal cells · Placenta-derived decidua stromal cells

\footnotetext{
Abstract

Background/Aims: Hemorrhagic cystitis (HC) is a serious complication after hematopoietic stem cell transplantation (HSCT). Stromal cells have been tested as therapy for HC. Decidua stromal cells (DSCs) protect the fetus from the mother's immune system. Methods: Eleven patients with $\mathrm{HC}$ of grades 3-4 were treated with DSCs after HSCT. The median age was 33 years (range $8-50$ ), and the median dose of DSCs was $1.5 \times 10^{6} / \mathrm{kg}$ (range $0.7-2.5$ ). The patients were given 1 dose (1-4). Results: In 5 patients, HC disappeared within 5 days after DSC infusion. Patients who received DSCs within 3 days after the start of $\mathrm{HC}$ had a duration of $\mathrm{HC}$ of 5 days and a shorter duration of pain than patients who were given DSCs later $(p=0.02)$. Three patients received DSCs prepared
}

in albumin instead of $A B$-plasma and tended to have a shorter duration of pain $(p=0.07)$. There was no infusion toxicity. Adverse events were those often seen after HSCT. Nine of the 11 patients (82\%) were alive 1 year after HSCT. Conclusions: Based on this pilot study, we started a randomized, placebocontrolled double-blind study using 2 doses of $1 \times 10^{6} \mathrm{DSCs} /$ $\mathrm{kg}$ suspended in albumin for treatment of early $\mathrm{HC}$.

(c) 2018 S. Karger AG, Basel

\section{Introduction}

Allogeneic hematopoietic stem cell transplantation (HSCT) is an established therapy for the treatment of hematological malignancies, severe aplastic anemia, and certain rare congenital metabolic defects $[1,2]$. The side effects of HSCT include toxicity of the conditioning regimen, bacterial, viral, and fungal infections as a result of immunosuppression, and graft-versus-host disease (GVHD) [3].

\section{KARGER}

(c) 2018 S. Karger AG, Basel

E-Mail karger@karger.com

www.karger.com/aha
Olle Ringdén, $\mathrm{MD}, \mathrm{PhD}$

Karolinska Institutet, Department of LABMED, Translational Cell Therapy Research (TCR), Kliniskt Forskningscentrum (KFC), NOVUM, Plan 6, Hälsovägen 7-9 SE-141 57 Huddinge (Sweden)

E-Mail olle.ringden@ki.se 
Hemorrhagic cystitis (HC) may occur after HSCT either as early-onset disease due to conditioning toxicity, or late-onset disease associated with GVHD or viral infections such as $\mathrm{BK}$ virus, adenovirus, and cytomegalovirus (CMV) [4-9]. The incidence of HC after HSCT has been reported to range from 10 to $70 \%$. There is no effective treatment, and 1-year mortality in patients with moderate-to-severe $\mathrm{HC}$ is $55-70 \%$ [8]. Treatments that have been tried for HC include hyperhydration and diuretics, oral prostaglandin E2, catheterization for bladder irrigation and clot removal, cystoscopy to cauterize bleeding points, bladder irrigation, analgesics, antispasmodics, antivirals including vidarabine, ribavirin, and cidofovir, estrogens, and hyperbaric oxygen $[10,11]$. Severe cases may be treated with urethral catheterization, nephrostomy, dialysis, and ligation of hypogastric arteries with or without cystectomy $[12,13]$.

Mesenchymal stromal cells (MSCs) suppress alloantigen-induced $\mathrm{T}$ cells in vitro and have immunomodulatory and anti-inflammatory effects combined with low immunogenicity [14-16]. We introduced MSCs as a treatment for severe steroid-refractory acute GVHD and HC [17-19]. Recently, the feasibility of MSCs as a treatment for HC was confirmed by others [20,21].

The term placenta and its adjacent tissues provide a ready source of stromal cells $[22,23]$. We isolated maternal decidua stromal cells (DSCs) from the fetal membranes of term placentas that were obtained after caesarian section $[24,25]$. The DSCs are immunosuppressive in vitro, and they express surface markers that are important for homing to inflamed tissues [24,25]. DSCs differ from bone marrow (BM)-MSCs in several aspects: they are half the size, more immunosuppressive, need direct contact to show the immunomodulatory effect, have a better expansion capacity, and do not differentiate well to cartilage and bone [24-26]. We have used DSCs after HSCT to treat severe acute GVHD, chronic GVHD, and acute respiratory distress syndrome, with positive responses in the vast majority of patients [27-29]. There are also in vitro data to suggest that DSCs promote clotting, which is in line with the fast recovery after postpartum hemorrhaging [26]. In this study, we wanted to find an optimal treatment for HC using DSCs, to be able to continue with a prospective double-blind, placebo-controlled study and test the possible efficacy.

\section{Materials and Methods}

\section{Study Design}

This was a prospective pilot study investigating safety and efficacy. The primary endpoint was the disappearance of macro- scopic hematuria. Secondary endpoints included infusion toxicity, side effects, time to disappearance of pain, infections, causes of death, and acute and chronic GVHD.

Grading of $H C$

$\mathrm{HC}$ was graded from 0 to 4 according to the scale proposed by Droller et al. [30]: 0 meant that there was no hematuria, 1 that there was microscopic hematuria, 2 that there was macroscopic hematuria, 3 that there was macroscopic hematuria with clots, and 4 that there was obstructive clotting perhaps requiring invasive clot evacuation. The patient's pain was graded from 0 to 3 according to the level of analgesia required: 0 required no analgesics, 1 needed oral administration of paracetamol, 2 required oral administration of opiates, and 3 needed intravenous administration of opiates and/ or epidural administration of analgesics. The pain level reported in this study was the highest level of pain experienced by the patient during active $\mathrm{HC}$.

\section{Patients}

Three patients had myelodysplastic syndrome and 1 had also developed severe aplastic anemia. Six had acute myeloid leukemia, 1 had acute lymphoblastic leukemia, and 1 had chronic myeloid leukemia. Eight patients with grade $3 \mathrm{HC}$ and 3 patients with grade $4 \mathrm{HC}$ were treated with DSCs. The patient characteristics are detailed in Table 1. The patients signed written informed consent to receive DSCs for HC. All patients failed treatment with oral prostaglandin E2 and hyperhydration with diuretics.

\section{Ethical Approval and Regulatory Issues}

Ethical approval was provided by the Ethics Committee, Karolinska Institutet, to collect stromal cells from placenta after caesarian sections (2009/418-31/4), and to use DSCs clinically for tissue toxicity, hemorrhages, and GVHD (2010/452-31/4). Approval was also given to perform a randomized study for $\mathrm{HC}$ to compare DSCs with placebo (2013/2147-31/3). The placenta donor signed a written informed consent form. According to agreement from the Swedish Food and Drug Agency (because it was an academic study), the trial was started while working on approval for chemistry, manufacturing, and control.

From 2012 to 2014, DCSs were used under the so-called hospital exemption according to the declaration of Helsinki and approved by the Swedish Drug Agency as a pilot study. The GMP laboratories at the Blood Bank, Karolinska University Hospital, Huddinge, used for culturing of DSCs is licensed as a tissue establishment by the Health and Social Care Inspectorate of Sweden. They also stated that DSCs fulfil their criteria of quality and safety (6.1.3.42994/2013). During recent years we have been working on obtaining approval for the production of DSCs according to the EU regulation (1394/2007). The trial is registered at Clinical Trials NCT02172963.

\section{Transplantation Procedure}

The patients with myeloid malignancies were treated with busulfan (16 mg/kg) and cyclophosphamide (Cy; $120 \mathrm{mg} / \mathrm{kg}$; Table 1) [31]. The patient with acute lymphoblastic leukemia was treated with $\mathrm{Cy}$ and fractionated total body irradiation (12 Gy). The MDS patient who developed aplastic anemia was treated with reducedintensity conditioning consisting of fludarabine $\left(30 \mathrm{mg} / \mathrm{m}^{2}\right)$ for 6 days followed by Cy $(120 \mathrm{mg} / \mathrm{kg})$ [32]. Grafts were from 2 HLAidentical siblings, 6 matched unrelated donors, 2 HLA-mismatched unrelated donors, and 1 unrelated cord blood transplant. The re- 
Table 1. Patient characteristics

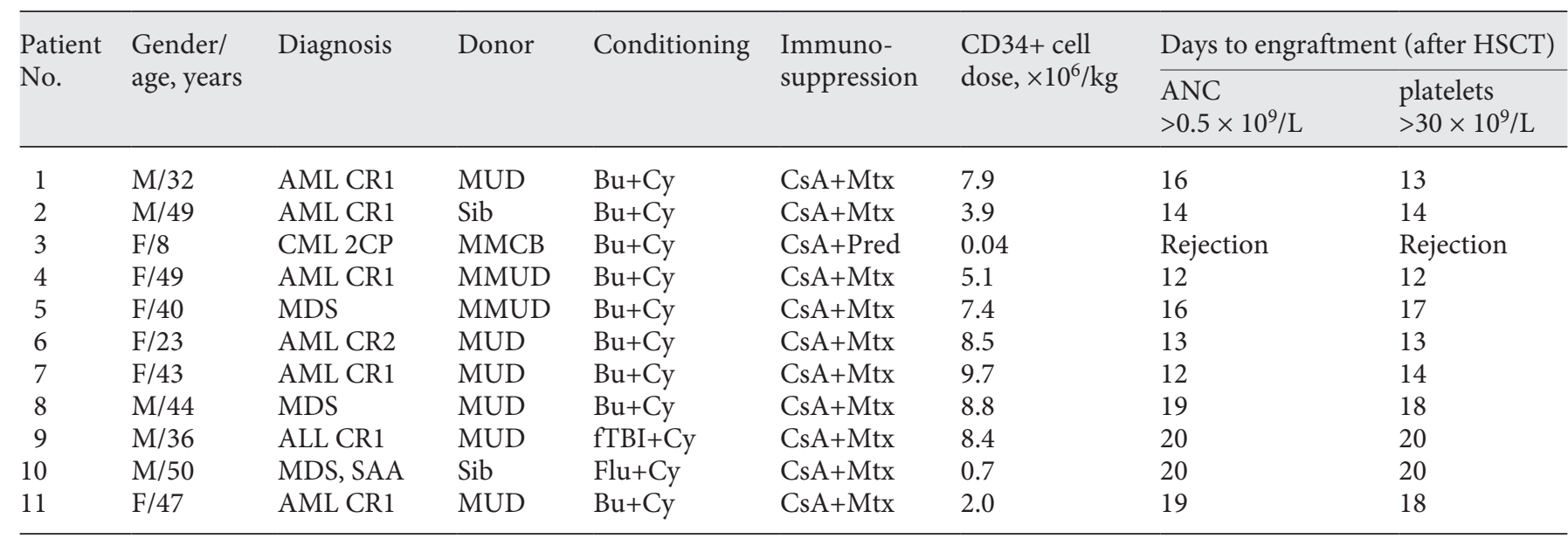

M, male; F, female; AML, acute myeloid leukemia; MUD, matched unrelated donor; Bu, busulfan; Cy, cyclophosphamide; CsA, cyclosporine; Mtx, methotrexate; Sib, HLA-identical sibling; CML, chronic myeloid leukemia; MMCB, HLA-mismatched cord blood; MMUD, HLA-mismatched unrelated donor; Pred, prednisolone; MDS, myelodysplastic syndrome; SAA, severe aplastic anemia; fTBI, fractionated total body irradiation; Flu, fludarabine.

cipient of the cord blood graft had a rejection and was regrafted with her mother's haploidentical graft. Antithymocyte globulin was given to 10 patients before transplant [33]. GVHD prophylaxis consisted of cyclosporine and short-term methotrexate [34]. The recipient of the cord blood graft received cyclosporine and prednisolone. The patients were treated in reverse isolation or at home during the pancytopenic phase if they lived within 2-h driving distance from the hospital [35]. Acute GVHD was graded according to the Seattle criteria [36]. Chronic GVHD was graded as mild, moderate, or severe $[37,38]$.

\section{Isolation and Preparation of DSCs}

DSCs were isolated from the fetal membranes of term placentas that were obtained after caesarian section, as described in detail previously $[25,28]$. Briefly, human term placentas were obtained from healthy mothers during elective caesarean section births, after obtaining informed consent. All donors were seronegative for HIV, hepatitis A and B, and syphilis. CMV was not checked for because it is not carried by stromal cells [39]. The placenta was put in a sterile container and immediately transferred to the laboratory for processing. The fetal membrane was carefully dissected from the placenta in a class II biosafety flow-cabinet and transferred to a sterile beaker for extensive washing in Hyclone phosphate-buffered saline (PBS; Thermo Fisher Scientific, Waltham, MA, USA; http://www.thermofisher.com). The tissue was cut into smaller pieces and transferred to 50-mL Falcon tubes (BD Biosciences, San Jose, CA, USA; http://www.bdbiosciences.com). An equal volume of trypsin/EDTA (Thermo Fisher Scientific) was added to the tissue for $10 \mathrm{~min}$ at $37^{\circ} \mathrm{C}$ and was then discarded. The tissue was then incubated twice in trypsin/EDTA for $40 \mathrm{~min}$ at $37^{\circ} \mathrm{C}$, and the trypsin digests were pooled and washed in Dulbecco's modified Eagle's medium (DMEM; Thermo Fisher Scientific) containing $10 \%$ fetal calf serum (Thermo Fisher Scientific) and penicillin-streptomycin (Invitrogen, Carlsbad, CA, USA; http:// www.invitrogen.com). The digested cells were counted and seeded at $2.9 \times 10^{5}$ cells per $\mathrm{cm}^{2}$ in Nunc T175 flasks (Nunc A/S, Roskilde, Denmark) using complete DMEM. The remains of the fetal membrane were washed in complete DMEM and cut into $3-$ to $4-\mathrm{cm}^{2}$ pieces, and these were spread out and incubated in T175 flasks. The tissue explants were removed from the flasks when colonies of fibroblast-like cells appeared after approximately 1 week of culture. When the cells from the trypsin-digested suspension and from the tissue explants were about 90-95\% confluent, the cells were harvested with trypsin/EDTA, washed in complete DMEM, and seeded in new T175 flasks at $2.9 \times 10^{3}$ cells per $\mathrm{cm}^{2}$ in complete DMEM. The cells were cultured to passage 2 or 3 and frozen slowly in complete DMEM containing 10\% dimethyl sulfoxide (WAK-Chemie Medical GmbH, Steinbach, Germany). DSCs were expanded and cultured under good manufacturing practice conditions using a room with reversed isolation, a sterile bench, and a separate incubator for cells from each donor. In all cases, DSCs were evaluated for mycoplasma or bacterial infection before infusion.

\section{Karyotype Analysis of DSCs}

Karyotype analysis with conventional CTG-banding of DSC cultures was performed using standard cytogenetic procedures. At least 11 metaphase nuclei from each sample were analyzed.

\section{Characterization and Administration of DSCs}

The DSCs expressed CD29, CD44, CD49d, CD73, CD90, CD105, CD54, HLA class I, programmed death ligand-1 (PD-L1), and PD-L2 [28]. The details of expression and variability were previously published in detail [28]. The cells were negative for the hematopoietic markers CD45 and CD34, and for epithelial (EpCAM) and endothelial (CD31) markers. They showed a poor differentiation capacity to bone, fat, and cartilage [24]. Before infusion, the DSCs given to 8 patients were thawed in PBS supplemented with $10 \%$ AB plasma. Three patients were given DSCs dissolved 
Table 2. DSC data and clinical presentation of the study patients

\begin{tabular}{|c|c|c|c|c|c|c|c|c|c|c|c|c|}
\hline \multirow[t]{2}{*}{$\begin{array}{l}\text { Case } \\
\text { No. }\end{array}$} & \multicolumn{2}{|c|}{$\begin{array}{l}\text { Hemorrhagic } \\
\text { cystitis }\end{array}$} & \multirow{2}{*}{$\begin{array}{l}\text { Days to } \\
\text { DSC } \\
\text { infusion } \\
\text { after HC }\end{array}$} & \multirow[t]{2}{*}{$\begin{array}{l}\text { Pas- } \\
\text { sage }\end{array}$} & \multirow{2}{*}{$\begin{array}{l}\text { DSC } \\
\text { cell dose, } \\
\times 10^{6} / \mathrm{kg}\end{array}$} & \multirow[t]{2}{*}{$\begin{array}{l}\text { Viability, } \\
\%\end{array}$} & \multirow[t]{2}{*}{ Solution } & \multirow{2}{*}{$\begin{array}{l}\text { DSC } \\
\text { infusions, } \\
n\end{array}$} & \multirow{2}{*}{$\begin{array}{l}\text { Days to resolution } \\
\text { of macroscopic } \\
\text { hematuria after } \\
\text { DSC treatment }\end{array}$} & \multicolumn{2}{|c|}{ GVHD } & \multirow[t]{2}{*}{ Outcome } \\
\hline & $\begin{array}{l}\text { day of } \\
\text { onset }\end{array}$ & grade & & & & & & & & $\begin{array}{l}\text { acute } \\
\text { grade }\end{array}$ & chronic & \\
\hline 1 & 58 & 3 & 9 & 2 & 1.5 & 83 & $\mathrm{AB}$ & 1 & 2 & III & Mild & $\begin{array}{l}\text { MOF, sepsis, died on day } \\
581\end{array}$ \\
\hline 3 & 42 & 4 & 51 & 3 & 2.0 & 86 & $\mathrm{AB}$ & 1 & $\begin{array}{l}\text { 3, transient } \\
\text { disappearance } \\
\text { of } \mathrm{HC}\end{array}$ & No & No & $\begin{array}{l}\text { Rejected CB graft; } \\
\text { re-transplanted with a } \\
\text { haploidentical maternal } \\
\text { graft; alive and well after } \\
3 \text { years and } 6 \text { months, but } \\
\text { HC data are unavailable }\end{array}$ \\
\hline 6 & 56 & 3 & 10 & 3 & 1.4 & 91 & $\mathrm{AB}$ & 1 & $\begin{array}{l}\text { Intermittent } \\
\text { to day } 65\end{array}$ & No & Mild & $\begin{array}{l}\text { Died from relapse after } \\
363 \text { days }\end{array}$ \\
\hline 7 & 27 & 3 & 8 & 3 & 2.1 & 86 & $\mathrm{AB}$ & 1 & 11 & I & No & $\begin{array}{l}\text { Alive and well after } 3 \text { years } \\
\text { and } 7 \text { months }\end{array}$ \\
\hline 8 & 41 & 3 & 1 & 4 & 2.5 & 94 & $\mathrm{AB}$ & 1 & 5 & II & $\begin{array}{l}\text { Obstruc- } \\
\text { tive lung } \\
\text { disease? }\end{array}$ & $\begin{array}{l}\text { Alive after } 3 \text { years and } \\
4 \text { months }\end{array}$ \\
\hline 9 & 32 & 3 & 0 & 4 & 1.5 & 95 & Alb & 1 & 5 & III & - & $\begin{array}{l}\text { Died from sepsis and } \\
\text { pneumonia on day } 411\end{array}$ \\
\hline
\end{tabular}

HC, hemorrhagic cystitis; DSC, decidua stromal cell; GVHD, graft-versus-host disease, CB, cord blood; CMV, cytomegalovirus; EBV, Epstein-Barr virus; MOF, multiple organ failure; AB, DSCs suspended in saline and $10 \% \mathrm{AB}$ plasma; Alb, DSCs suspended in saline and $5 \%$ albumin.

in PBS and 5\% albumin. The DSCs were infused through a central venous line. For adults, the line was flushed with $5 \mathrm{~mL}$ of saline with $50 \mathrm{IU}$ heparin/mL both before and after the infusion of DSCs. Children were given lower doses of heparin.

\section{Infections}

Viruses such as adenovirus, Epstein-Barr virus (EBV), and CMV were detected using PCR. CMV reactivation was assumed if there were $>2,000$ copies detected in blood by PCR and, combined with this, CMV disease was defined as a symptomatic infection [40]. Superficial, cutaneous, and oral mycoses were not taken into account.

\section{Statistics}

Continuous variables were calculated using the Mann-Whitney $U$ test due to the small number of patients and their nonnor- mal distribution. Any $p$ values $<0.05$ were considered significant. Analysis was performed using Statistica 12 software (StatSoft ${ }^{\circledR}$, Tulsa, MD, USA).

\section{Results}

The median time from HSCT to HC was 41 days (1358). The overall median duration of $\mathrm{HC}$ was 22 days (5361). The first 8 patients were given 1 dose ranging from 1.3 to $2.5 \times 10^{6} \mathrm{DSCs} / \mathrm{kg}$. The last 3 patients were given 1 , 4 , and 2 doses of DSCs, respectively. The doses were between 0.7 and $1.7 \times 10^{6} / \mathrm{kg}$. The median viabilities of the 


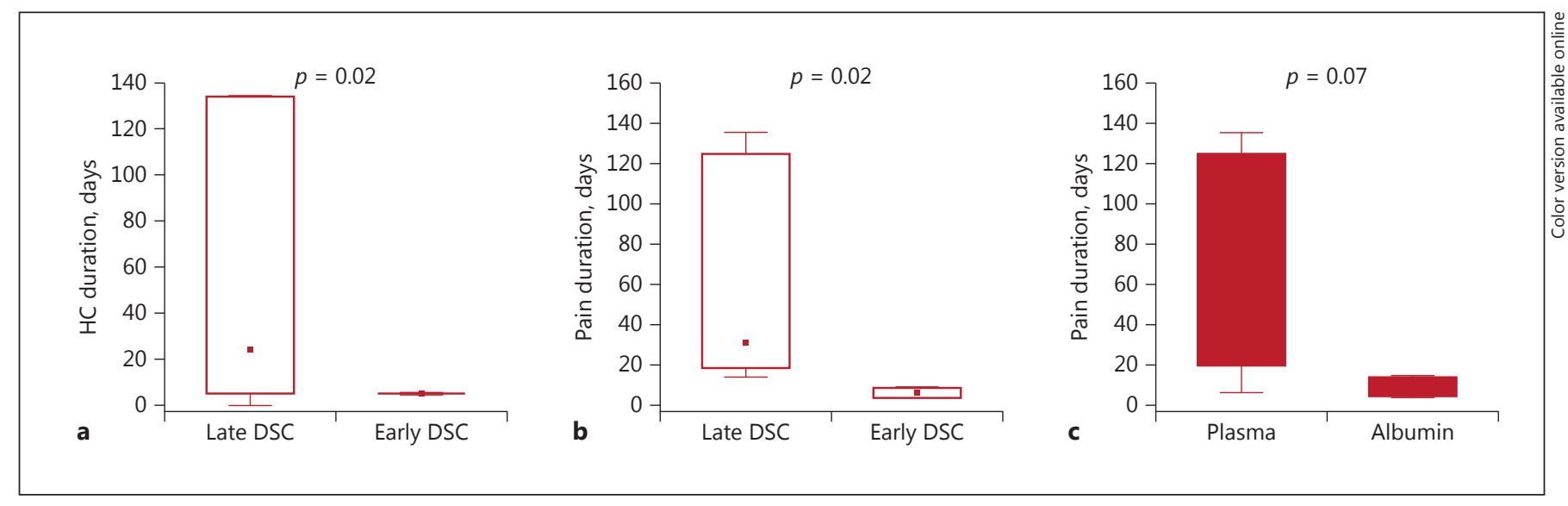

Fig. 1. a Duration of macroscopic hematuria in patients who were given DSCs within 3 days (early DSC treatment), or later after the start of HC $(p=0.02)$. b Duration of pain after the start of HC in patients who were treated with DSCs within 3 days (early DSC treatment) or later $(p=0.02)$. c Duration of pain after the start of HC in patients who were treated with DSCs suspended in saline with $10 \% \mathrm{AB}$ plasma $(n=8)$ or in saline with $5 \%$ albumin $(n=3)$.

DSCs in PBS with AB or albumin supplementation were $87 \%$ (75-94) and 95\% (91-99), respectively $(p<0.01)$. All cultured DSCs were negative for bacterial or mycoplasma infection; moreover, no karyotype abnormality was detected in cultured DSCs.

In 5 of the patients who were treated with DSCs, HC defined as macroscopic hematuria disappeared within 5 days after infusion with DSCs (patients 1, 4, 8, 9, and 11; Table 2). Patient 1 had recurrent $\mathrm{HC}$ of grade 3 , which was treated with DSCs after 9 days. He had clots, pain requiring opiates, and 4+ hematuria at the time of infusion with DSCs. Macroscopic hematuria did not recur after infusion and the pain disappeared after 17 days. In 3 patients (No. 5-7), macroscopic hematuria disappeared on day 11,24 , and 65 after DSC infusion. One patient (No. 3) improved clinically and had less pain, but there was no improvement in the grade of HC. No further data regarding HC status were retrieved since she was sent to her home county. She is, however, still alive and well at the time of writing. Two patients (No. 2 and 10) died from causes other than HC, but they had macroscopic hematuria at the time of death.

We compared 3 patients who received early DSC intervention less than 3 days after the appearance of $\mathrm{HC}$ with the remaining patients $(n=7)$. In all 3 patients, macroscopic hematuria disappeared after 5 days, as compared to a median time of 31 days (8-361) in those who had a later intervention ( $p=0.02$; Fig. 1a). Two of the patients are alive, but 1 died a year later due to pneumonia.

At the time of treatment, 3 patients had grade 2 pain and 8 patients had grade 3 pain. The median duration of pain was 21 days (4-135). The patients who had a DSC infusion within 3 days of the appearance of $\mathrm{HC}(n=3)$ were free of pain after a median time interval of 6 days (4-9), as compared to the other patients in the study $(n=$ 8 ) who were pain-free 31 days (14-135) after the appearance of $\mathrm{HC}(p=0.02$; Fig. $1 b)$.

The 3 patients who received DSCs in albumin-supplemented PBS rather than AB plasma-supplemented PBS tended to have a shorter duration of pain than the other patients in the study group (Fig. 1c; $p=0.07$ ). The patients spent a median of 14 days $(2-141)$ in hospital after treatment with DSCs for HC.

\section{Infections}

Infections were compared before and after the infusion of DSCs. Bacteremia were seen in 5 patients before DSC infusion and in 3 also after DSC infusion. Candidemia was diagnosed in 1 patient (No. 1) before infusion with DSCs, but in none after infusion. Herpes simplex virus infection was seen in 3 patients before infusion and in none after infusion. CMV reactivation was diagnosed in 5 patients before infusion, but in none after infusion. CMV disease was diagnosed in 1 patient before DSC infusion and in another after infusion. Adenovirus was diagnosed in 3 patients before infusion and in 4 after infusion. $\mathrm{BK}$ virus was diagnosed in 2 patients before infusion and in 2 after infusion. After infusion with DSCs, the following viruses were diagnosed: varicella-zoster virus $(n=3)$, EBV (2), coronavirus (1), influenza A virus (1), and norovirus (1). 


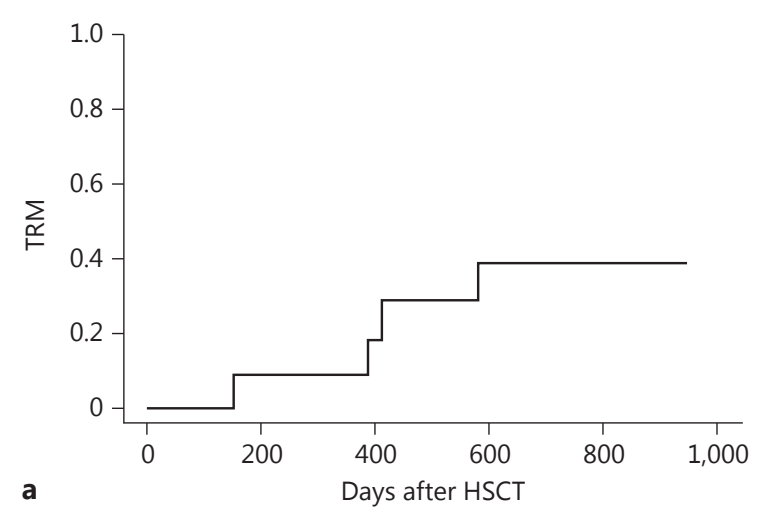

a

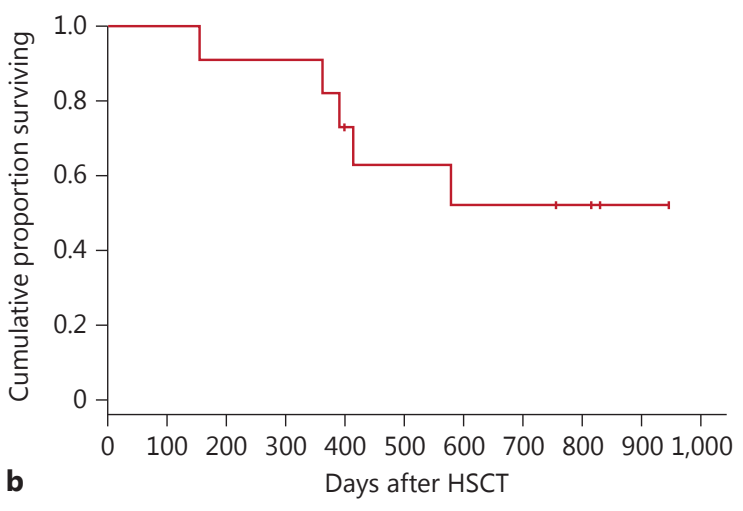

Fig. 2. a Time to and cumulative incidence of TRM in 11 patients who were treated for HC with DSCs (1 year 9\%, 2 years 39\%). b Overall survival time after stem cell transplantation in 11 patients who were treated for HC with DSCs (1 year 82\%, 2 years $52 \%)$.

\section{Severe Adverse Events and Causes of Death}

Infusion toxicity was not seen in any of the patients. Patient 1 developed acute GVHD of grade III 2 months after he was treated for HC. He was given DSCs and improved, but later developed a chemotherapy-induced cardiomyopathy together with liver and kidney failure. $\mathrm{He}$ died 181 days after HSCT from septicemia and gastrointestinal hemorrhage. Patient 2 had several bacterial and viral infections, and a suspected addisonian crisis, and died of cardiac failure 389 days after HSCT while still suffering from macroscopic hematuria. Patient 6 died of leukemic relapse a year after HSCT.

In patient $8, \mathrm{HC}$ symptoms disappeared 5 days after infusion and the pain disappeared after 6 days. However, he has since contracted several viral infections and

Placenta-Derived Stromal Cells for Severe $\mathrm{HC}$ is suffering from chronic thrombocytopenia and obstructive lung disease, which may be a sign of chronic GVHD. He has had no other symptoms of chronic GVHD.

Patient 9 had early recovery of hematuria and pain and later developed grade III acute GVHD that was responsive to steroids. He died from adenovirus pneumonia and septicemia 411 days after HSCT.

Patient 10, who had aplastic anemia subsequent to therapy for myelodysplastic syndrome, developed grade $4 \mathrm{HC} 13$ days after HSCT. He improved temporarily in $\mathrm{HC}$ after each DSC infusion and received in total 4 DSC infusions for HC. He needed a boost of donor cells due to graft failure (ANC $<0.5 \times 10^{9} / \mathrm{L}$ ) 2 months after his last DSC infusion. He had a difficult course, with CMV reactivation being treated with intravenous ganciclovir, foscarnet, maribavir, and CMV-cytotoxic T cells. EBV reactivation was treated with rituximab. Due to graft failure, he was treated with donor lymphocyte infusions and subsequently with booster marrow that was depleted of $\alpha-\beta-T$ cells. A month after the last DSC infusion, he had dyspnea and a pulmonary veno-occlusive disease was suspected. He died of Klebsiella septicemia and pneumonia 153 days after HSCT. Autopsy and microscopy showed intra-alveolar hemorrhaging and no thromboembolism in the lung tissue.

\section{GVHD and Survival}

Five of the patients developed grade II/III acute GVHD (Table 2). Four developed acute GVHD grade II to III before $\mathrm{HC}$ and DSC infusion. Patient 1 developed grade III acute GVHD 2 months after the HC and DSC infusion. Three patients developed mild GVHD and 1 developed severe chronic GVHD. One patient had obstructive bronchiolitis.

Transplant-related mortality (TRM) was $9 \%$ at 1 year and $39 \%$ at 2 years (Fig. 2a). One-year survival was $82 \%$ and 2 -year survival was $52 \%$ (Fig. 2b).

\section{Discussion}

This study was the first investigation of the effect of a novel treatment using infusion with DSCs as a therapy for the treatment of HC in HSCT patients. Because DSCs induce coagulation more effectively than BM-MSCs, they were selected for the treatment of $\mathrm{HC}$ in this pilot study [26].

Five out of the 11 patients experienced the disappearance of HC symptoms after DSC intervention. In addi- 
tion, 3 other patients experienced the transient disappearance of symptoms. The most interesting group was that of the 3 patients who received DSCs within 3 days of the start of HC. These patients were all free from macroscopic hematuria within 5 days and they were pain free within 9 days. In a retrospective survey, Hassan et al. [8] found that the median duration of hematuria in $\mathrm{HC}$ of grade 3 or higher, without stromal cell therapy, was 42 days. This was twice as long as the 22 days observed for the 11 patients in the present study.

Previous data indicate that BM-MSCs can elicit a response in the majority of patients who suffer from $\mathrm{HC}$ $[19,41]$. In one of the studies, macroscopic hematuria disappeared within a median period of 3 days in the responders, who were all treated early after the appearance of HC. Furthermore, in a study by Wang et al. [21], 6 out of 7 patients received MSC infusions within 3 days of the start of HC. In that study, MSCs from Wharton jelly were used, which gave a median time to remission of 18 days (8-60) for HC of grade 3 or 4. In GVHD, younger patients appear to have a better response to MSC therapy than older patients [42]. In the study by Wang et al. [21], only 1 patient was over 30 years of age. In contrast, in the present study, only 2 patients were below 30 years of age.

Stromal cell therapy has so far been reported to be safe, with little infusion toxicity [14-16, 18, 19, 42, 43]. We did not see any infusion toxicity in any of the 17 DSC infusions in this study. Because of the low toxicity, stromal cells seem better than all other therapies used for severe $\mathrm{HC}$, such as bladder irrigation, cystoscopy to cauterize bleeding points, and others [10-13]. DSC is favorable to other sources of stromal cells as no invasive procedure is needed and there is unlimited supply.

It should be noted that $\mathrm{HC}$ appears more frequently in high-risk patients who undergo HSCT using myeloablative conditioning $[7,8]$. In our previous experience, patients with grade $3 \mathrm{HC}$ have a 1 -year TRM of $55 \%$, and those with grade 4 or grade $5 \mathrm{HC}$ have a TRM of $71 \%$ [8]. The patients treated with DSCs for HC have a more favorable TRM than those treated conservatively [8]. Regarding toxicity using DSCs, we performed a detailed study including 44 patients treated for acute GVHD or $\mathrm{HC}$ and compared them to historical controls [44]. It was a detailed study of safety and side-effects using a novel clinical therapy: DSCs for acute GVHD in 34 patients, and HC in 10 patients. The study also included controls receiving conventional therapy. Severe adverse events and cause of death were similar in the DSC group and the controls. The control patients more often died from acute GVHD.
The present study is the efficacy evaluation using DSCs for HC.

Acute GVHD grade II/III was seen in 5 of the $11 \mathrm{HC}$ patients. There is a correlation between acute GVHD and HC [9]. Four had GVHD before HC and 1 developed it later.

Regarding infections, herpes simplex virus infection and bacteremia were more common before DSC infusion than after. This corresponds to the time of onset of $\mathrm{HC}$, as bacteremia and HSV infection often appears during the pancytopenic phase after HSCT [10]. CMV reactivation was seen in 5 patients and only before infusion with DSCs. An in vitro study showed that MSCs did not impair CMV-cytotoxic T cells, in contrast to their effect on alloreactive $\mathrm{T}$ cells [45]. These observations might at least suggest that, although immunosuppressive, DSCs may not increase the risk of CMV reactivation and infection.

So far, there is limited experience of using human DSCs in experimental animals. A study showed that mice treated with 9-Gy total body irradiation, HSCT, and very high doses of human DSCs $\left(40 \times 10^{-6} / \mathrm{kg}\right)$ died from pulmonary embolism [46].

The source of MSCs that should be used in the treatment of HC is debatable. Both BM-MSCs and Wharton jelly-derived MSCs have shown promising results [16, 19, $21,41]$. There are several theoretical advantages to using DSCs over BM-MSCs for HC, such as smaller size, better coagulation capacity, less differentiation to cartilage and bone, and an increased expression of integrins that may facilitate migration to inflamed tissue $[25,26,28]$.

To conclude, early treatment within 3 days of the start of $\mathrm{HC}$ and the use of DSCs thawed in albumin-supplemented saline appear to be beneficial based on the results of this small pilot study. DSCs washed and dissolved in PBS and 5\% albumin had a significantly better viability than those dissolved in PBS and 10\% AB serum. Patients with acute GVHD treated with DSC dissolved in albumin had a 1 -year survival of $76 \%$ as opposed to $44 \%$ in those receiving DSC dissolved in $A B$ serum [47]. The side effects are those commonly seen in HSCT patients. Based on this pilot study, a randomized placebo-controlled study has been started to evaluate the safety and efficacy of using DSCs for the treatment of HC in patients with grade 3-4 HC and a viral infection found within a minimum of 3 days, and who do not respond to forced diuresis, prostaglandin E2, and antivirals. 


\section{Acknowledgements}

We thank the staff of the Center for Allogeneic Stem Cell Transplantation for competent and compassionate care of the HSCT patients. We thank Inger Holmström and Moa Thorin for assistance in the preparation of this article. O.R. was supported by grants from the Swedish Cancer Society (CAN2013/671), the Swedish Research Council (K2014-64X-05971-34-4), the Children's Cancer Foundation (PROJ12/021), the Cancer Society in Stockholm (111293), and Karolinska Institutet.

\section{Disclosure Statement}

The authors have no conflicts of interest to declare.

\section{References}

1 Thomas ED, Buckner CD, Banaji M, Clift RA, Fefer A, Flournoy N, Goodell BW, Hickman RO, Lerner KG, Neiman PE, Sale GE, Sanders JE, Singer J, Stevens M, Storb R, Weiden PL: One hundred patients with acute leukemia treated by chemotherapy, total body irradiation, and allogeneic marrow transplantation. Blood 1977;49:511-533.

2 Hoogerbrugge PM, Brouwer OF, Bordigoni P, Ringden O, Kapaun P, Ortega JJ, O’Meara A, Cornu G, Souillet G, Frappaz D, Blanche S Fischer A; The European Group for Bone Marrow Transplantation: Allogeneic bone marrow transplantation for lysosomal storage diseases. Lancet 1995;345:1398-1402.

3 Ringden O: Immunotherapy by allogeneic stem cell transplantation. Adv Cancer Res 2007;97C:25-60.

4 de Padua Silva L, Patah PA, Saliba RM, Szewczyk NA, Gilman L, Neumann J, Han XY, Tarrand J, Ribeiro R, Gulbis A, Shpall EJ, Jones R, Popat U, Walker JA, Petropoulos D, Chiattone A, Stewart J, El-Zimaity M, Anderlini P, Giralt S, Champlin RE, de Lima M: Hemorrhagic cystitis after allogeneic hematopoietic stem cell transplants is the complex result of BK virus infection, preparative regimen intensity and donor type. Haematologica 2010;95:1183-1190.

5 Cesaro S, Hirsch HH, Faraci M, Owoc-Lempach J, Beltrame A, Tendas A, Baltadakis I, Dalle JH, Koc Y, Toporski J, Styczynski J, Yesilipek MA, Heinz W, Caniglia M, Rascon J, Fauser AA, Michallet M, Lopez-Corral L, Neuburger S, Tridello G, Einsele H; European Group for Blood and Marrow Transportation: Cidofovir for BK virus-associated hemorrhagic cystitis: a retrospective study. Clin Infect Dis 2009;49:233-240.

6 Childs R, Sanchez C, Engler H, Preuss J, Rosenfeld S, Dunbar C, van Rhee F, Plante M, Phang S, Barrett AJ: High incidence of adenoand polyomavirus-induced hemorrhagic cystitis in bone marrow allotransplantation for hematological malignancy following $\mathrm{T}$ cell depletion and cyclosporine. Bone Marrow Transplant 1998;22:889-893.

7 Giraud G, Priftakis P, Bogdanovic G, Remberger M, Dubrulle M, Hau A, Gutmark R, Mattson J, Svahn BM, Ringden O, Winiarski
J, Ljungman P, Dalianis T: BK-viruria and haemorrhagic cystitis are more frequent in allogeneic haematopoietic stem cell transplant patients receiving full conditioning and unrelated-HLA-mismatched grafts. Bone Marrow Transplant 2008;41:737-742.

8 Hassan Z, Remberger M, Svenberg P, Elbander M, Omazic B, Mattsson J, Conrad R, Svahn BM, Ahlgren A, Sairafi D, Aschan J, Le Blanc K, Barkholt L, Ringden O: Hemorrhagic cystitis: a retrospective single-center survey. Clin Transplant 2007;21:659-667.

9 Ost L, Lonnqvist B, Eriksson L, Ljungman P, Ringden O: Hemorrhagic cystitis - a manifestation of graft versus host disease? Bone Marrow Transplant 1987;2:19-25.

10 Potácová Z DT, Le Blanc K, Ringden O: Hemorrhagic cystitis; in Wingard JR, Gastineau DA, Leather HL, Snyder EL, Szczepiorkowski ZM (eds): Hematopoietic Stem Cell Transplantation: A Handbook for Clinicians. Bethesda, AABB, 2015, pp 529-538.

11 Chong KT, Hampson NB, Corman JM: Early hyperbaric oxygen therapy improves outcome for radiation-induced hemorrhagic cystitis. Urology 2005;65:649-653.

12 Palandri F, Bonifazi F, Rossi C, Falcioni S, Arpinati M, Giannini MB, Ansaloni F, Bandini G, Baccarani M: Successful treatment of severe hemorrhagic cystitis with selective vesical artery embolization. Bone Marrow Transplant 2005;35:529-530.

13 Garderet L, Bittencourt H, Sebe P, Kaliski A, Claisse JP, Esperou H, Ribaud P, Estrade V, Gluckman E, Gattegno B: Cystectomy for severe hemorrhagic cystitis in allogeneic stem cell transplant recipients. Transplantation 2000;70:1807-1811.

14 Bernardo ME, Locatelli F, Fibbe WE: Mesenchymal stromal cells. Ann NY Acad Sci 2009; 1176:101-117.

15 English K, French A, Wood KJ: Mesenchymal stromal cells: facilitators of successful transplantation? Cell Stem Cell 2010;7:431442.

16 Ringden O, Le Blanc K: Mesenchymal stem cells for treatment of acute and chronic graftversus-host disease, tissue toxicity and hemorrhages. Best Pract Res Clin Haematol 2011; 24:65-72.
17 Le Blanc K, Rasmusson I, Sundberg B, Gotherstrom C, Hassan M, Uzunel M, Ringden O: Treatment of severe acute graft-versushost disease with third party haploidentical mesenchymal stem cells. Lancet 2004;363: 1439-1441

18 Ringden O, Uzunel M, Rasmusson I, Remberger M, Sundberg B, Lonnies H, Marschall HU, Dlugosz A, Szakos A, Hassan Z, Omazic B, Aschan J, Barkholt L, Le Blanc K: Mesenchymal stem cells for treatment of therapyresistant graft-versus-host disease. Transplantation 2006;81:1390-1397.

19 Ringden O, Uzunel M, Sundberg B, Lonnies L, Nava S, Gustafsson J, Henningsohn L, Le Blanc K: Tissue repair using allogeneic mesenchymal stem cells for hemorrhagic cystitis, pneumomediastinum and perforated colon. Leukemia 2007;21:2271-2276.

20 Kebriaei P: Mesenchymal stromal cells: The magic band-aid? Acta Haematol 2015;133 70-71.

21 Wang Y, Chen F, Gu B, Chen G, Chang H, Wu $\mathrm{D}$ : Mesenchymal stromal cells as an adjuvant treatment for severe late-onset hemorrhagic cystitis after allogeneic hematopoietic stem cell transplantation. Acta Haematol 2015;133: 72-77.

22 Brooke G, Rossetti T, Pelekanos R, Ilic N, Murray P, Hancock S, Antonenas V, Huang G, Gottlieb D, Bradstock K, Atkinson K: Manufacturing of human placenta-derived mesenchymal stem cells for clinical trials. $\mathrm{Br}$ J Haematol 2009; 144:571-579.

23 In't Anker PS, Scherjon SA, Kleijburg-van der Keur C, de Groot-Swings GM, Claas FH, Fibbe WE, Kanhai HH: Isolation of mesenchymal stem cells of fetal or maternal origin from human placenta. Stem Cells 2004;22:13381345.

24 Erkers T, Nava S, Yosef J, Ringden O, Kaipe $\mathrm{H}$ : Decidual stromal cells promote regulatory $\mathrm{T}$ cells and suppress alloreactivity in a cell contact-dependent manner. Stem Cells Dev 2013;22:2596-2605.

25 Karlsson H, Erkers T, Nava S, Ruhm S, Westgren M, Ringden O: Stromal cells from term fetal membrane are highly suppressive in allogeneic settings in vitro. Clin Exp Immunol 2012;167:543-555. 
26 Moll G, Ignatowicz L, Catar R, Luecht C, Sadeghi B, Hamad O, Jungebluth P, Dragun D, Schmidtchen A, Ringden O: Different procoagulant activity of therapeutic mesenchymal stromal cells derived from bone marrow and placental decidua. Stem Cells Dev 2015;24: 2269-2279.

27 Erkers T, Kaipe H, Nava S, Mollden P, Gustafsson B, Axelsson R, Ringden O: Treatment of severe chronic graft-versus-host disease with decidual stromal cells and tracing with ${ }^{111}$ Indium radiolabeling. Stem Cells Dev 2015;24:253-263.

28 Ringden O, Erkers T, Nava S, Uzunel M, Iwarsson E, Conrad R, Westgren M, Mattsson J, Kaipe H: Fetal membrane cells for treatment of steroid-refractory acute graft-versushost disease. Stem Cells 2013;31:592-601.

29 Ringden O, Solders M, Erkers T, Nava S, Mollden P, Hultcrantz M, Kaipe H, Mattsson J: Successful reversal of acute lung injury using placenta-derived decidual stromal cells. J Stem Cell Res Ther 2014;4:244.

30 Droller MJ, Saral R, Santos G: Prevention of cyclophosphamide-induced hemorrhagic cystitis. Urology 1982;20:256-258.

31 Ringden O, Remberger M, Ruutu T, Nikoskelainen J, Volin L, Vindelov L, Parkkali T, Lenhoff S, Sallerfors B, Mellander L, Ljungman P, Jacobsen N: Increased risk of chronic graftversus-host disease, obstructive bronchiolitis, and alopecia with busulfan versus total body irradiation: long-term results of a randomized trial in allogeneic marrow recipients with leukemia. Nordic Bone Marrow Transplantation group. Blood 1999;93:2196-2201.

32 Hentschke P, Barkholt L, Uzunel M, Mattsson J, Wersall P, Pisa P, Martola J, Albiin N, Wernerson $A$, Soderberg $M$, Remberger $M$, Thorne A, Ringden O: Low-intensity conditioning and hematopoietic stem cell transplantation in patients with renal and colon carcinoma. Bone Marrow Transplant 2003; 31:253-261.

33 Remberger M, Svahn BM, Mattsson J, Ringden O: Dose study of thymoglobulin during conditioning for unrelated donor allogeneic stem-cell transplantation. Transplantation 2004;78:122-127.
34 Storb R, Deeg HJ, Pepe M, Appelbaum F, Anasetti C, Beatty P, Bensinger W, Berenson R, Buckner CD, Clift R: Methotrexate and cyclosporine versus cyclosporine alone for prophylaxis of graft-versus-host disease in patients given HLA-identical marrow grafts for leukemia: long-term follow-up of a controlled trial. Blood 1989;73:1729-1734.

35 Svahn BM, Remberger M, Myrback KE, Holmberg K, Eriksson B, Hentschke P, Aschan J, Barkholt L, Ringden O: Home care during the pancytopenic phase after allogeneic hematopoietic stem cell transplantation is advantageous compared with hospital care. Blood 2002;100:4317-4324.

36 Storb R, Thomas ED: Graft-versus-host disease in dog and man: the Seattle experience. Immunol Rev 1985;88:215-238.

37 Carlens S, Ringden O, Remberger M, Lonnqvist B, Hagglund H, Klaesson S, Mattsson J, Svahn BM, Winiarski J, Ljungman P, Aschan J: Risk factors for chronic graft-versus-host disease after bone marrow transplantation: a retrospective single centre analysis. Bone Marrow Transplant 1998;22:755-761.

38 Lee SJ, Klein JP, Barrett AJ, Ringden O, Antin JH, Cahn JY, Carabasi MH, Gale RP, Giralt S, Hale GA, Ilhan O, McCarthy PL, Socie G, Verdonck LF, Weisdorf DI, Horowitz MM: Severity of chronic graft-versus-host disease: association with treatment-related mortality and relapse. Blood 2002;100:406-414.

39 Sundin M, Orvell C, Rasmusson I, Sundberg B, Ringden O, Le Blanc K: Mesenchymal stem cells are susceptible to human herpesviruses, but viral DNA cannot be detected in the healthy seropositive individual. Bone Marrow Transplant 2006;37:1051-1059.

40 Ljungman P, Aschan J, Lewensohn-Fuchs I, Carlens S, Larsson K, Lonnqvist B, Mattsson J, Sparrelid E, Winiarski J, Ringden O: Results of different strategies for reducing cytomegalovirus-associated mortality in allogeneic stem cell transplant recipients. Transplantation 1998;66:1330-1334.
41 Ringden O, Leblanc K: Pooled MSCs for treatment of severe hemorrhage. Bone Marrow Transplant 2011;46:1158-1160.

42 Le Blanc K, Frassoni F, Ball L, Locatelli F, Roelofs H, Lewis I, Lanino E, Sundberg B, Bernardo ME, Remberger M, Dini G, Egeler RM, Bacigalupo A, Fibbe W, Ringden O; Developmental Committee of the European Group for Blood and Marrow Transportation: Mesenchymal stem cells for treatment of steroid-resistant, severe, acute graft-versushost disease: a phase II study. Lancet 2008; 371:1579-1586.

43 Lalu MM, McIntyre L, Pugliese C, Fergusson D, Winston BW, Marshall JC, Granton J, Stewart DJ, Canadian Critical Care Trials G: Safety of cell therapy with mesenchymal stromal cells (SafeCell): a systematic review and meta-analysis of clinical trials. PLoS One 2012;7:e47559.

44 Baygan A, Aronsson-Kurttila W, Moretti G, Tibert B, Dahllof G, Klingspor L, Gustafsson B, Khoein B, Moll G, Hausmann C, Svahn BM, Westgren M, Remberger M, Sadeghi B, Ringden O: Safety and side effects of using placenta-derived decidual stromal cells for graft-versus-host disease and hemorrhagic cystitis. Front Immunol 2017;8:795.

45 Karlsson H, Samarasinghe S, Ball LM, Sundberg B, Lankester AC, Dazzi F, Uzunel M, Rao K, Veys P, Le Blanc K, Ringden O, Amrolia PJ: Mesenchymal stem cells exert differential effects on alloantigen and virus-specific T-cell responses. Blood 2008;112:532-541.

46 Sadeghi B, Heshmati Y, Khoein B, Kaipe H, Uzunel M, Walfridsson J, Ringden O: Xenoimmunosuppressive properties of human decidual stromal cells in mouse models of alloreactivity in vitro and in vivo. Cytotherapy 2015;17:1732-1745.

47 Ringden O, Baygan A, Remberger M, Gustafsson B, Winiarski J, Khoein B, Klingspor L, Westgren M, Sadeghi B: Placenta-derived decidua stromal cells for treatment of severe acute graft-versus-host disease. Stem Cells Transl Med, submitted. 